Available Online at http://journal.unismuh.ac.id/index.php/otoritas

Otoritas : Jurnal Ilmu Pemerintahan, 8 (2), October 2018, 143-158

\title{
Factors Affecting Employees' Religiosity at the Public Workplace in Kepulauan Riau, Indonesia
}

\author{
Wayu Eko Yudiatmaja ${ }^{*}$, , Edison1, Tri Samnuzulsari ${ }^{2}$ \\ ${ }_{1}^{1}$ Department of Public Administration, Faculty of Social and Political Sciences \\ Universitas Maritim Raja Ali Haji, Jl. Raya Dompak, Tanjungpinang, Indonesia 29111, Indonesia. \\ ${ }^{2}$ Department of Sociology, Faculty of Social and Political Sciences Universitas Maritim Raja Ali Haji, \\ Jl. Raya Dompak, Tanjungpinang, Indonesia 29111, Indonesia.
}

Received: 3 August 2018; Revised: 3 September 2018; Accepted: 19 September 2018

\begin{abstract}
Currently, religiosity has become an emerging topic in the literature of public administration. Most research examines the dimensions of religiosity and their relationships with various organizational dimensions. Much less attention, however, has been paid to analyze the factors affecting employees' religiosity, particularly in the context of public organization. Therefore, this study investigates the critical factors affecting employees' religiosity. This study is conducted on 262 public servants in the Government of Kepulauan Riau Province. An extensive literature and questionnaire were used to identify the factors affecting employees' religiosity. This study applied statistical methods with ranking and factor analyses to verify and analyze the factors. Ranking analysis results the most important factors, namely family religious activity. Factor analysis constructs 5 components, including personal belief system, implementing religious belief, family religiousness, religious practices, and belief on the death. Theoretical, methodological, and practical implications are provided in the light of these findings.
\end{abstract}

Keywords: Religiosity; Public Workplace; Ranking and Factor Analysis

How to Cite: Yudiatmaja, W. E., Edison, E., \& Samnuzulsari, T. (2018). Factors Affecting Employees' Religiosity at the Public Workplace in Kepulauan Riau, Indonesia. Otoritas : Jurnal Ilmu Pemerintahan, 8(2), 143-158.

Permalink/DOI: https://doi.org/10.26618/ojip.v8i2.1442

${ }^{*}$ Corresponding Author.

E-Mail : wayuguci@umrah.ac.id

Copyright (C) 2018, Otoritas : Jurnal Ilmu Pemerintahan, ISSN: 2088-3706 (Print), ISSN: 2502-9320 (Online) 


\section{INTRODUCTION}

Since long time ago, religion has been acknowledged as the factor affecting attitudes and human behavior. Max Weber (1930) - a reputable social scientistfor instance, has introduced "the Protestant Ethic" as an inner motive of the European Protestants in creating Industrial Revolution and the rise of capitalism in the Western world. Then, in his widely known theory about the achievement motive, Harvard psychologist, David McClelland also presented that the difference of faith tradition has an implication to the many factors, including motivation (McClelland, 1961; 1965). More currently, Friedland \& Alford (1991) also noted that religion is one of the core institutionalized belief systems in Western society along with capitalist markets, bureaucratic states, democracy, and the nuclear family.

The scholars of public administration have also given a special attention on religious issues in the context of public sector. Effendi (1999) stated that religion is an integral part of the study of public administration, especially in a plural country. Houston, Freeman, \& Feldman (2008) found that the government employees generally are more religious and possess less secular behaviors than private workers. Nevertheless, some other scholars have addressed that religiosity tend to be causally associated to several modes of attitudes, behavior, and orientation among individuals in the public workplace (Farmer, 2005; Hula, JacksonElmoore, \& Reese, 2007; Lowery, 2005).

The main problem to investigate religiosity is the difficulty to define religion and religiosity because it contains complex dimensions to define (Cornwall, Albrecht, Cunningham, \& Pitcher, 1986; DeJong, Faulkner, \& Warland, 1976; Hackney \& Sanders, 2003). Yet, most scholars agree that religiosity is the reflection or the implementation of the practices of religious faith (Hill et al., 2000; Kenneth I
Pargament, 1999). The concept of religion defined by influential Anthropologist, Clifford Geertz, might have widely accepted. Geertz (1973) argued that religion is a system of symbols which acts to establish powerful, pervasive, and long-lasting moods and motivations in men by formulating conceptions of a general order of existence and clothing these conceptions with such an aura of factuality that the moods and motivations seem uniquely realistic.

The literature of public administration has stressed the relationships between religiosity and various factors in the context of public organization. Overall, the results of prior studies examining religiosity and organizational factors find that the employees who are more religious have more positive motivation to deliver public service (Bisesi \& Lidman, 2009; Bruce, 2000; Freeman \& Houston, 2010; King, 2007) and have a higher orientation toward job security (Bozeman \& Murdock, 2015). It means religiosity plays important role in creating better public service delivery.

The literature has also discussed the vary of the aspects of religiosity (Egbert, Mickley, \& Coeling, 2004; Hill \& Hood, 1999; Koenig, Al Zaben, Khalifa, \& Al Shohaib, 2015). It is derived from many dimensions of religious values put into practiced by the people in their social life. Nonetheless, most of the study is conducted in the context of management (Gundolf \& Filser, 2013) and psychology (Gorsuch, 1988; Hill \& Edwards, 2013). Surprisingly, there are still limited number of the studies examining this issue in the context of public administration.

Hill and Hood (1999) measured and scaled the important dimensions of religiosity by identifying key literatures. They found 125 measurements of religiosity classified into 17 categories, namely beliefs, attitudes, religious orientation, faith development, fundamentalism, attitudes toward death, congregational involve- 
ment, and satisfaction. Other categories found by them are similar with the classification by Fetzer Institute (1999), such as experiences, meaning, values, forgiveness, practices, coping, support, history, commitment, and preference.

Egbert et al. (2004) investigated the measures of religiosity by reviewing some references of several researches in the fields of psychology, sociology, anthropology, nursing, and medicine. Three measures of religiosity have been grouped into several factors, namely extrinsic and intrinsic religiosity (e.g. religious orientation, age universal, and intrinsic religious motivation), spiritual well-being, and religious coping. King \& Crowther (2004) also presented existing measures of religiosity. They noted that there are several measures of religiosity, such as religious orientation scale, quest, intrinsic religious motivation, religion, and religious values.

Koenig et al. (2015) reviewed the prior literatures about the dimensions of religiosity. They concluded three scales of religiosity, which are single dimension (e.g. attachment to God, daily spiritual experiences, and religious coping), multidimensional scales (e.g. Duke Religion Index, Springfield, Fetzer), and religion specific scales (Muslim, Santosh-Francis, Buddhist). Unfortunately, the literature reviewed by Koenig et al. (2015) were cited from the measure of religiosity developed in Protestant and Catholic Christian populations.

Mahudin, Noor, Dzulkifli, \& Janon (2016) designed the measures of religiosity among Muslims based on Islamic perspective (Islam, Iman, and Ihsan) in Malaysia. The final scale yielded one factor with 10 underlying items, for instances strive for both worldly affairs and avoid behavior (Iman), teach the family members the greatness of Allah and remember Allah (Islam), pleased with what he/she has, and fear of Allah (Ihsan). These measures are in line with Muslim religios- ity developed by Krauss, Hamzah, Juhari \& Abd. Hamid (2005), namely Islamic worldview and religious personality.

In the present study, we sought to identify and rank the factors affecting employees' religiosity. Accordingly, the aim of this study is to examine the factors affecting employees' religiosity and rank the factors affecting employees' religiosity in the context of public workplace. The public servants of the Government of Kepulauan Riau Province are chosen to provide the proper findings and expand the existing study stream contexts.

The recent study specifically contributes to the literature of public administration in three ways. First, this study focused on the crucial factors affecting employees' religiosity where it still has little pay attention by previous research. The previous work focused on examining the influence of religiosity on various variable in organizational setting (Sood \& Nasu, 1995; Tracey, 2012). Second, this study provides new perspective on the study of religiosity in the context of public organization because it examines the employees' religiosity in the setting of public workplace. There are still little attention of the scholars of public administration in employing the study of religiosity in the context of public workplace (Cunningham, 2005; deHaven-Smith, 2003; King, 2007). Lastly, the recent study use factor and rank analyses in incorporating employees' religiosity. It can enrich the methodological perspective of the study of religiosity because the prior work mostly use regression analysis (Weaver et al., 2002; Weaver, Flannelly, Garbarino, Figley, \& Flannelly, 2003).

In attempting to accomplish the objective of the study, we first address the literature of religiosity. Second, the relevant literature and theories from management and organization studies are briefly reviewed to develop and present the potential factors affecting religiosity among the public servants. Research methods is 
Available Online at http://journal.unismuh.ac.id/index.php/otoritas

Otoritas : Jurnal Ilmu Pemerintahan, 8 (2), October, 2018, 146

then followed. Finally, the implications to the body of knowledge and conclusions are presented.

\section{RESEARCH METHODS}

Following Wang \& Yuan (2011), in this study, we used two stages to formulate the crucial factors affecting employees' religiosity, namely literature review and questionnaire, presented in Figure 1. At the last stage, questionnaire was distributed as an appropriate procedure for collecting quantitative data. The questionnaire consisted of two sections. The first section contained the general informations about the respondents. The second section consisted of 26 potential factors affecting employees' religiosity. The theoretical factors used in this study were adapted from the previous research (Chadwick \& Top, 1993; Delaney, Miller, \& Bisonó, 2013; Hill \& Hood, 1999; Hyman \& Handal, 2006; Mahudin et al., 2016).

The 5-point Likert scale ranging from strongly disagree (1) to strongly agree (5) was employed in this study because it used to commonly used in the behavioral research (MacKenzie, Podsakoff,
\& Podsakoff, 2011). The data to be presented here were gathered from 262 respondent come from 32 organizations in the Government of Kepulauan Riau Province. The number of sample was chosen from 349 of the total of population using Cochcran's (1962) formula. Thus, the response rate of this study was $75.07 \%$.

In this study, we used rank and factor analyses by using SPSS 23.0 to find out the crucial factor affecting religiosity among the employees. Rank analysis was employed to rank the crucial factors affecting employees' religiosity. Factor analysis was a statistical method useful to verify and classify a large number of variables into the important dimensions (Hair Jr., Black, Babin, \& Anderson, 2010; Thompson, 2004).

Before processing factor analysis, several tests were required to determine the appropriateness of the factor analysis for factor extraction, which are the values of the Kaiser-Meyer-Olkin (KMO), the Barlet Test of Sphericity (BTS), and Measures of Sampling Adequacy (MSA). First, all items could be analyzed if the value of KMO was .5 or greater (Kaiser, 1974). Second, the value of BTS was higher than
Data collection methods
Aims

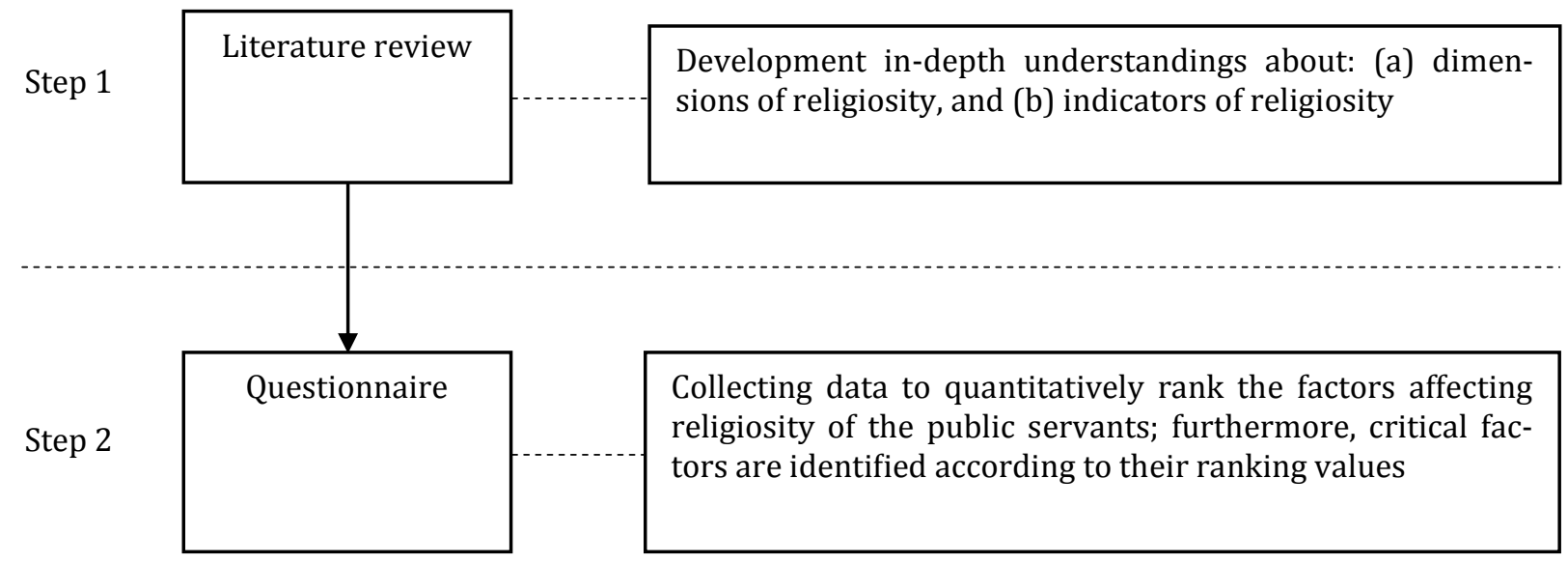

Figure 1. Data Collection Procedures

Source: Adapted from Wang \& Yuan, 2011 
Available Online at http://journal.unismuh.ac.id/index.php/otoritas

Otoritas : Jurnal Ilmu Pemerintahan, 8 (2), October, 2018, 147

Table 1. Description of Factors in the Questionnaire

Source: Developed from Cornwall et al.,1986; Chadwick \& Top,1993; Delaney, Miller, \&

Bisonó, 2013

\begin{tabular}{|c|c|c|}
\hline No & Factors & Description \\
\hline REL01 & Belief on the God & Belief on the existence of the God, the power and the \\
\hline REL02 & Belief the life after death & $\begin{array}{l}\text { role of the God in arranging the life in the world } \\
\text { Belief that the human will be death and responsible } \\
\text { their action during the world }\end{array}$ \\
\hline REL03 & Religious events & Activity related to the general religious faith \\
\hline REL04 & Belief on the scripture & $\begin{array}{l}\text { Belief that the scripture is the words of the God and } \\
\text { the truth of the content }\end{array}$ \\
\hline REL05 & Private religious practice & Always pray routinely to the God \\
\hline REL06 & Reading the scripture & $\begin{array}{l}\text { Reading the scripture and understanding the } \\
\text { meaning of each verse }\end{array}$ \\
\hline REL07 & Belief on the punishment of the God & $\begin{array}{l}\text { Belief that the good action will be paid with the good, } \\
\text { and vice versa }\end{array}$ \\
\hline REL08 & Alms activity & Giving an alms, religious meals, and etc to poor \\
\hline REL09 & Reading the religious books & Reading religious books and magazines \\
\hline REL10 & Social environment & $\begin{array}{l}\text { Always comfortable with the people in their social } \\
\text { environment }\end{array}$ \\
\hline REL11 & Belief on the apocalypse & Belief that the apocalypse will be happen \\
\hline REL12 & Belief the power of the God & $\begin{array}{l}\text { Belief that the God will answer prayers and give the } \\
\text { best for the slave }\end{array}$ \\
\hline REL13 & God blesses for their righteousness & $\begin{array}{l}\text { God will bless the people doing the righteousness } \\
\text { and help them }\end{array}$ \\
\hline REL14 & Belief the existence of Satan & $\begin{array}{l}\text { Belief that Satan is exist and always misleading the } \\
\text { human }\end{array}$ \\
\hline REL15 & Praying before conducting activity & $\begin{array}{l}\text { Always pray to the God in conducting every working } \\
\text { activities (before and after) }\end{array}$ \\
\hline REL16 & Family religious activity & Family member always implement religious faith \\
\hline REL17 & Requesting only to the God & Pray to the God to achieve their willing \\
\hline REL18 & Family praying activity & Family member is always routine worship \\
\hline REL19 & Religious environment & $\begin{array}{l}\text { Conditions of social environment (at home and } \\
\text { workplace) }\end{array}$ \\
\hline REL20 & Acceptance in social environment & $\begin{array}{l}\text { Response of the others to him/her at social } \\
\text { environment }\end{array}$ \\
\hline REL21 & Feeling at the worship place & $\begin{array}{l}\text { Attitude or behavior of the others toward him/her at } \\
\text { the worship place }\end{array}$ \\
\hline
\end{tabular}


Available Online at http://journal.unismuh.ac.id/index.php/otoritas

Otoritas : Jurnal Ilmu Pemerintahan, 8 (2), October, 2018, 148

1320.796 and the associated significance level was small $(p=.000)$. It means the correlation matrix was not identity matrix. The last one, the value of MSA was higher than .3 (Tabachnick \& Fidell, 2007).

\section{RESULTS AND DISCUSSION}

\section{Descriptive Statistics}

As a first step, we present the demographic background of the participants of this study. From the responses received, only 262 were revealed to be valid for analysis. Table 2 presents the demographic data. Female represented $50.4 \%$ of the respondents, which is not surprising because female population is growing up in Indonesian civil service (Muljono, 2013; Oey-Gardiner, 2002). The age group most represented in the survey was 31-40 years of age (40.7\%). Approximately $37.8 \%$ of respondents indicated that they have work for 5 years. Majority of the respondent was a permanent employee. The largest educational background group was undergraduate (52\%). The findings of the study can be generalized to the Government of Kepulauan Riau Province but it was not representative for total government employees of local governments in Indonesia. Thus, the results of this study can be interpreted with caution.

\section{Ranking of the Factors}

The purpose of this part is to identify the important factors affecting employees' religiosity. The level of importance of each factor is determined by the mean and standard deviation derived from the total sample. The one with the lower standard deviation is chosen as more important factor if two or more factors have the same mean value. A criteria is set in this study to identify these factors. It is useful to assess the factors with relatively high mean values indicating higher impacts in religiosity. The critical factors af-

Table 2. Demographic Information of the Respondents

Source: Processed from the questionnaire data, 2017

\begin{tabular}{|c|c|c|}
\hline & Frequency & Percentage \\
\hline \multicolumn{3}{|l|}{ Sex } \\
\hline Male & 130 & 49.6 \\
\hline Female & 132 & 50.4 \\
\hline \multicolumn{3}{|l|}{ Age (years) } \\
\hline$<26$ & 63 & 24.6 \\
\hline $26-30$ & 53 & 20.7 \\
\hline $31-40$ & 104 & 40.7 \\
\hline $41-50$ & 22 & 8.6 \\
\hline$>50$ & 14 & 5.5 \\
\hline \multicolumn{3}{|l|}{ Length of service } \\
\hline$<5$ & 93 & 37.8 \\
\hline $5-10$ & 91 & 37.0 \\
\hline $11-20$ & 43 & 17.4 \\
\hline $21-30$ & 15 & 6.1 \\
\hline$>30$ & 4 & 1.6 \\
\hline \multicolumn{3}{|l|}{ Classification of employee } \\
\hline Permanent employee & 145 & 57.5 \\
\hline Contract employee & 117 & 42.5 \\
\hline \multicolumn{3}{|l|}{ Educational background } \\
\hline Senior high school & 55 & 21.5 \\
\hline Diploma & 44 & 17.2 \\
\hline Undergraduate & 133 & 52.0 \\
\hline Graduate & 24 & 9.4 \\
\hline
\end{tabular}


fecting employees' religiosity are obtained from the factors with mean values greater than the average value of all mean values (.044). The factor analysis results are presented in Table 3.

In Table 3, we can see that there are 16 factors among 21 factors generating a mean value of greater than .044 . They are decided as critical factors affecting employees' religiosity. The top-four critical factors are "family religious activity", "belief the life after death", "belief the power of the God", and "alms activity" because their mean value are above .046. From the results, it also can be analyzed that there are only 4 factors related to non-personal belief, while the others depend on employees' personal belief system. These findings strengthen the conclusion that personal belief system plays an important role in affecting employees' religiosity at the public workplace.

"Family religious activity" takes the first position based on the research results, with .049 of mean value. It is wondrous result because the previous studies always placed belief on the God as the first critical factor (Chadwick \& Top, 1993; Hill \& Hood, 1999; Hyman \& Handal, 2006). Yet, in our study, family religious activity become the first important factor affecting employees' religiosity. It related to the practices of religious belief implemented by family members of the employee, such as prayer together. Hence, implementing religious belief by the family member influences employees' religiosity.

The second critical factor affecting employees' religiosity is "belief the life after death" (mean value: .047). This result is in line with some prior studies (Mahudin et al., 2016; O'Connell, 1975). Those employees who belief that there is the life after death have a belief on the afterlife. The afterlife is believed as the immortal life. Religiosity make the people to belief that the life in the world is only for a while (Peterson \& Greil, 1990). This believing encourages employees' behaviors and attitudes in the workplace. The believing that there is the life after death drives the employees to avoid various mistakes. They believe that it can make

Table 3. Ranking of Important Factors Affecting Employees' Religiosity Source: Processed from the research data, 2017

\begin{tabular}{llll}
\hline \multicolumn{1}{c}{ Factors } & Mean & Std. Deviation & Rank \\
\hline REL16 Family religious activity & .049 & .795 & 1 \\
REL02 Belief the life after death & .047 & .753 & 2 \\
REL12 Belief the power of the God & .047 & .755 & 3 \\
REL08 Alms activity & .047 & .764 & 4 \\
REL21 Feeling at the worship place & .046 & .748 & 5 \\
REL19 Religious environment & .045 & .722 & 6 \\
REL17 Requesting only to the God & .045 & .728 & 7 \\
REL15 Praying before conducting acitivity & .045 & .733 & 8 \\
REL07 Belief on the punishment of the God & .045 & .733 & 9 \\
REL13 God blesses for their righteousness & .045 & .734 & 10 \\
REL11 Belief on the apocalypse & .045 & .736 & 11 \\
REL04 Belief on the scripture & .044 & .705 & 12 \\
REL09 Reading the religious books & .044 & .705 & 13 \\
REL03 Religious events & .044 & .709 & 14 \\
REL06 Reading the scripture & .044 & .710 & 15 \\
REL18 Family praying activity & .044 & .719 & 16 \\
\hline
\end{tabular}


Available Online at http://journal.unismuh.ac.id/index.php/otoritas

Otoritas : Jurnal Ilmu Pemerintahan, 8 (2), October, 2018, 150

their life difficult in the afterlife. Thus, the life in the afterlife is determined by their behaviors in the world.

As a factor related to personal belief system, "belief the power of the God" was ranked the third place (mean value: .047) among all necessary factors. The result is similar with the findings provided by Westerman, Whitaker, \& Hardesty (2013) concluding that belief in God is a predicted factor to personal values in the workplace. The public servants believing the power of the God occasionally have a strong commitment to the public interest in their worklife. They have an empathy and compassion to the public. Religiosity encompasses their effort to do the best in their job.

It is also to be noticed that 5 factors in the list, typically including "requesting only to the God", "praying before conducting acitivity", "belief on the punishment of the God", "God blesses for their righteousness", and "belief on the apocalypse", are implementation of religious belief. The finding confirms the study of Delaney et al. (2013) on American Psychologists finding that most psychologists always pray to the God. In practical terms, the belief of the God have to be implemented in religious activities, such as praying to the God. The employees can pray before and after beginning their activities. It aims to expect the directions from the God. By praying, the employees try to encloser themselves to the God.

"Belief on the scripture", "reading

Table 4. Component Matrix after Varimax Rotation

Source: Processed from the research data, 2017

\begin{tabular}{|c|c|c|c|c|c|}
\hline & \multicolumn{5}{|c|}{ Component } \\
\hline & 1 & 2 & 3 & 4 & 5 \\
\hline God blesses for their righteousness & .777 & & & & \\
\hline Belief on the punishment of the God & .742 & & & & \\
\hline Belief on the apocalypse & .715 & & & & \\
\hline Alms activity & .713 & & & & \\
\hline Reading the religious books & .708 & & & & \\
\hline Belief the power of the God & .680 & & & & \\
\hline Feeling at the worship place & & .739 & & & \\
\hline Praying before conducting acitivity & & .670 & & & \\
\hline Reading the scripture & & .635 & & & \\
\hline Family religious activity & & .620 & & & \\
\hline Religious environment & & .516 & & & \\
\hline Belief on the scripture & & & .842 & & \\
\hline Family praying activity & & & .737 & & \\
\hline Religious events & & & & .860 & \\
\hline Requesting only to the God & & & & .770 & \\
\hline Belief the life after death & & & & & .839 \\
\hline
\end{tabular}

Extraction Method: Principal Component Analysis.

Rotation Method: Varimax with Kaiser Normalization.

a. Rotation converged in 6 iterations. 
Available Online at http://journal.unismuh.ac.id/index.php/otoritas

Otoritas : Jurnal Ilmu Pemerintahan, 8 (2), October, 2018, 151

the religious books", "religious events", reading the scripture, and "family praying activity" are non-personal belief gaining lower rank than personal belief system factors. It is also surprising to be explored, although many non-personal belief, including related factors have been categorized as important factors (Hoge, 1972; Wilkes, Burnett, \& Howell, 1986), it is ranked fairly low in our study in terms of its influence on employees' religiosity (mean value: .044-.045).

Based on the survey result, majority of the respondent $(82 \%)$ never obtained formally religious education. Probably, the employees try to enhance their religious belief by understanding secondary sources, for instances religious books or magazines, religious events, and praying together with their family.

\section{Factor Analysis of the Important Fac- tors}

As suggested by Hair, et al. (2010), we used factor analysis to overcome the problem of analyzing the structure of the correlations among a large number of variables, such as test scores and questionnaire responses, by defining a set of common underlying dimensions decided as the factors. To analyze the groupings might be exist among the critical factors, this statistical technique was utilized in this study.

Based on the critical factors in- volved in each group, the five components can be renamed as: (1) personal belief system, (2) implementing religious belief, (3) family religiousness, (4) religious practices, and (5) belief on the death.

"Personal belief system" component has more items than other components in this study. It consists of "God blesses for their righteousness", "belief on the punishment of the God", "belief on the apocalypse", "alms activity", "reading the religious books", and "belief the power of the God" related to the "hard" strength of an employee. This component accounts for $25.02 \%$ of the total variance (Table 5). Some scholars name the component as intrinsic religiousness (Donahue, 1985a, 1985b; Gorsuch \& McPherson, 1989).

God blesses for their righteousness, belief on the punishment of the God, belief on the apocalypse, alms activity, reading the religious books, and belief the power of the God are related to personal belief system. A high loading associated with this component is "God blesses for their righteousness" item, with .777 of the value of significance (Table 4). When the employees obtain the bless of the God, they have the believing that it is an impact of their righteousness. This is a crucial factor for employees' religiosity.

"Implementing religious belief" is the second component affecting employees' religiosity. There are five critical fac-

Table 5. Total Variance Explained for Critical Factors

Source: Processed from the research data, 2017

\begin{tabular}{llll}
\hline & Component & \multicolumn{2}{c}{ Extraction Sums of Squared Loadings } \\
& Total & \% of Variance & Cumulative \% \\
\hline 1 & 4.003 & 25.016 & 25.016 \\
2 & 2.903 & 18.144 & 43.16 \\
3 & 1.195 & 7.469 & 50.629 \\
4 & 1.019 & 6.368 & 56.997 \\
5 & 1 & 6.251 & 63.248 \\
Extraction method: principal component analysis & & & \\
\hline
\end{tabular}


tors in this component: "feeling at the worship place", "praying before conducting acitivity", "reading the scripture", "family religious activity", and "religious environment". This component accounts for $18.14 \%$ of the total variance explained among all critical factors (Table 5). Employees' always try to implement the religious belief in their workplace (GarciaZamor, 2003; Lewis \& Geroy, 2000). It related to the parctice of religious belief in real world. The employees with high religious level have a higher motivation to implement their belief.

"Family religiousness" component has two components, namely "belief on the scripture" and "family praying activity". Family religiousness affects behavior and attitude of the employees in the workplace. It means employees' attitude absolutely depend on religious environment in their family. Employees with highly religious family will have positive attitude and behavior. This study shows that this component accounts for $7.47 \%$ of the total variance explained among all critical factors (Table 5).

Family praying activity (table 4: significance .737) can greatly effect employees' religiosity. According to Dollahite \& Marks (2009) one of the religious process in the family is resolving conflict with prayer, repentance, and forgiveness. Prayer is an instrument to solve the vary of the problems faced by the employees, such as conflict, over loaded, and inequality payment.

"Religious practices" component contructs 2 items, including "religious events" and "requesting only to the God". This component accounts for $6.37 \%$ of the total variance explained among all critical factors (see Table 5). The employees always apply religious practices in their life, for instance praying five times regularly and pray to the God. Religious employees are the employee slightly conducting religious practices.

"Belief on the death" component has only one item, namely "belief the life after death". This component contributes for $6.25 \%$ of the total variance explained in the critical factor analysis (Table 5). This indicates that belief the life after death become an important role in affecting emploees' religiosity. Eventhough this factor is ranked relatively lower than other critical factors discussed previously, it also plays an important role in influencing employees' religiosity in the Indonesian local government.

This study offers several implications. From the theoretical side, our study contribute to accomplish the literature of public administration. First, this study offers an important understanding of what drives employees' religiosity in the context of public organization religiosity. Some prior researchs have identified several dimensions and items of religiosity (e.g. Koenig et al., 2015; Mahudin et al., 2016; Voas, McAndrew, \& Storm, 2013), but they had not yet identify and rank the crucial factors affecting employees' religiosity. Second, this study employed rank and factor analysis by using statistical package in measuring the crucial factors affecting employees' religiosity. Finally, this study also offers valuable insights in human resources management literature in an understudied Indonesian context (Bennington \& Habir, 2003).

In terms of the methodological perspective, this study adds the existing literature because it used rank and factor analyses. Although the prior research are mostly quantitative (Benefiel, Fry, \& Geigle, 2014), they had not used rank and factor analyses yet. Majority of the study employed correlation or regression method. The method measured how strong the independent variable influenced employees' religiosity.

From a practical point of view, this study is also worthwhile to the manager in the public sector organizations. The identified factors affecting employees' religiosity in the present study should assist 
the managers to develop the religious faith in the public organizations. It can enhance positive individual behavior in the public workplace, including creativity, commitment, and performance (Cash \& Gray, 2000; Day, 2005; Osman-Gani, Hashim, \& Ismail, 2012). However, managers should also expand other various dimensions because the dimensions identified in this study might not be exhaustive.

As the first study about religiosity at the public workplace in Indonesia, we realize that this study has several limitations. Therefore, we will present the limitations of the study. First, we used various factors of religiosity come from Western literature and philosophy. It can bring in a serious debate because it is sometimes inappropriate to generalize the religiosity in the context of Indonesian which is the one of largest Muslim country in the world. Due to come from Western social scientific approaches, it is insufficient to explore Islamic faith (Ghorbani, Watson, \& Khan, 2007; Murken \& Shah, 2002) because the differences of social and cultural context can generate different stripe of religiosity (Hill \& Pargament, 2003).

Second, the present study use quantitative approach by using survey. It is only a continuance of prior research of this issue because most previous studies have used quantitative approach (Miller \& Teel, 2011; Weaver, Flannelly, Flannelly, Koenig, \& Larson, 1998; Weaver et al., 2003). Thus, the future studies should consider not only different approach but also multi-perspective to identify the crucial factors affecting employees' religiosity, in particular qualitative or mixedmethod. Might the further research should apply the integrating between social-scientific and philosophical perspective as provided by Benefiel (2005).

Lastly, the current study is limited in the context of Indonesian public sector. It can not represent the different context of the worldwide because the result only represent the Government of Kepulauan Rau Province. The findings of this study provide a basic framework to identify employees' religiosity in the context of Indonesian public workplace. It can not be expanded in the context of other public administrations.

\section{CONCLUSION}

Various dimensions have examined and received as the predominant factors of religiosity designed to be a generic dimensions, especially in the context of business organizations. The present study examines the crucial factors affecting employees' religiosity in the context of Indonesian public organization. As a result, there are 16 important factors from 21 crucial factors affecting employees' religiosity. It groups into 5 components, including "personal belief system" (component 1), "implementing religious belief" (component 2), "family religiousness" (component 3), "religious practices" (component 4), and "belief on the death" (component 5). This study provides worthy directions to the academics and practitioners in developing and utilizing factors affecting employees' religiosity.

\section{ACKNOWLEDGEMENT}

This article is written from a part of the results of our research funded by the Board of Research, Community Service and Quality Assurance (LP3M) of Universitas Maritim Raja Ali Haji based on the Agreement No. 001/UN53.02/KontrakPUPT/2018. Therefore, we are deeply grateful to the LP3M of Universitas Maritim Raja Ali Haji. We wish to also express our gratitude to Dhani Akbar for his assistance correcting the grammar of the manuscript.

\section{REFERENCES}

Benefiel, M. (2005). The second half of the journey: Spiritual leadership for 
Available Online at http://journal.unismuh.ac.id/index.php/otoritas

Otoritas : Jurnal Ilmu Pemerintahan, 8 (2), October, 2018, 154

organizational transformation. The Leadership Quarterly, 16(5), 723747.

Benefiel, M., Fry, L. W., \& Geigle, D. (2014). Spirituality and religion in the workplace: History, theory, and research. Psychology of Religion and Spirituality, 6(3), 175-187.

Bennington, L., \& Habir, A. D. (2003). Human resource management in Indonesia. Human Resource Management Review, 13(3), 373-392.

Bisesi, M., \& Lidman, R. (2009). Compassion and power: Religion, spirituality, and public administration. International Journal of Public Administration, 32(1), 4-23.

Bozeman, B., \& Murdock, A. (2015). Public managers' religiosity: Impacts on work attitudes and perceptions of coworkers. In K. Schedler \& I. Proeller (Eds.), Cultural aspects of public management reform (Research in public policy analysis and management, volume 16) (pp. 119144). Amsterdam, The Netherlands: Emerald Group Publishing.

Bruce, W. M. (2000). Public administrator attitudes about spirituality: An exploratory study. American Review of Public Administration, 30(4), 460472.

Cash, K. C., \& Gray, G. R. (2000). A framework for accommodating religion and spirituality in the workplace. Academy of Management Executive, 14(3), 124-133.

Chadwick, B. A., \& Top, B. L. (1993). Religiosity and delinquency among LDS adolescents. Journal for the Scientific Study of Religion, 32(1), 5167.
Cochran, W. G. (1962). Sampling techniques. Bombay: Asia Publishing House.

Cornwall, M., Albrecht, S. L., Cunningham, P. H., \& Pitcher, B. L. (1986). The dimensions of religiosity: A conceptual model with an empirical test. Review of Religious Research, 27 (3), 226-244.

Cunningham, R. (2005). Religion and public administration - The unacknowledged common (and competitive ground). International Journal of Public Administration, 28 (11-12), 943-955.

Day, N. E. (2005). Religion in the workplace: Correlates and consequences of individual behavior. Journal of Management, Spirituality and Religion, 2(1), 104-135.

deHaven-Smith, L. (2003). What Jesus says to public administration. International Journal of Organization Theory and Behavior, 6(1), 90-118.

DeJong, G. F., Faulkner, J. E., \& Warland, R. H. (1976). Dimensions of religiosity reconsidered: Evidence from a crosscultural study. Social Forces, 54(4), 866-889.

Delaney, H. D., Miller, W. R., \& Bisonó, A. M. (2013). Religiosity and spirituality among psychologists: A survey of clinician members of the American Psychological Association. Spirituality in Clinical Practice, 1(S), 95-106.

Dollahite, D. C., \& Marks, L. D. (2009). A conceptual model of family and religious processes in highly religious families. Review of Religious Research, 50(4), 373-391.

Donahue, M. J. (1985a). Intrinsic and 
Available Online at http://journal.unismuh.ac.id/index.php/otoritas

Otoritas : Jurnal Ilmu Pemerintahan, 8 (2), October, 2018, 155

extrinsic religiousness: Review and meta-analysis. Journal for the Scientific Study of Religion, 48(2), 400 -419 .

Donahue, M. J. (1985b). Intrinsic and extrinsic religiousness: The empirical research. Journal for the Scientific Study of Religion, 24(4), 418-423.

Effendi, S. (1999). Administrasi publik, pembangunan dan kemajemukan etnis [Public administration, development and diversity of ethnicity]. JKAP (Jurnal Kebijakan Dan Administrasi Publik, 3(2), 1-10.

Egbert, N., Mickley, J., \& Coeling, H. (2004). A review and application of social scientific measures of religiosity and spirituality: Assessing a missing component in health communication research. Health Communication, 16(1), 7-27.

Farmer, J. D. (2005). Talking about religion. Administrative Theory \& Praxis, 27(1), 182-195.

Fetzer Institute. (1999). Multidimensional measurement of religiousness/ spirituality for use in health research: A report of the Fetzer Institute/ National Institute on Aging Working Group. Kalamazoo, MI: Fetzer Institute.

Freeman, P. K., \& Houston, D. J. (2010). Belonging, believing, behaving: The religious character of public servants. Administration \& Society, 42(6), 694719.

Friedland, R., \& Alford, R. P. (1991). Bringing society back in: Symbols, practices, and institutional contradictions. In W. W. Powell \& P. J. DiMaggio (Eds.), The new institutionalism in organizational analysis (pp. 232-263). Chicago: The
University of Chicago Press.

Garcia-Zamor, J.-C. (2003). Workplace spirituality and organizational performance. Public Administration Review, 63(3), 355-363.

Geertz, C. (1973). The interpretation of cultures. New York: Basic Books.

Ghorbani, N., Watson, P. J., \& Khan, Z. H. (2007). Theoretical, empirical, and potential ideological dimensions of using Western conceptualizations to measure Muslim religious commitments. Journal of Muslim Mental Health, 2(2), 113-131.

Gorsuch, R. L. (1988). Psychology of religion. Annual Review of Psychology, 39, 201-221.

Gorsuch, R. L., \& McPherson, S. E. (1989). Intrinsic/extrinsic measurement: I/E -revised and single-item scales. Journal for the Scientific Study of Religion, 28(3), 348-354.

Gundolf, K., \& Filser, M. (2013). Management research and religion: $\mathrm{A}$ citation analysis. Journal of Business Ethics, 112(1), 177-185.

Hackney, C. H., \& Sanders, G. S. (2003). Religiosity and mental health: A meta -analysis of recent studies. Journal for the Scientific Study of Religion, 42(1), 43-55.

Hair Jr., J. F., Black, W. C., Babin, B. J., \& Anderson, R. E. (2010). Multivariate data analysis, seventh edition. Upper Saddle River, NJ: Prentice Hall.

Hill, P. C., \& Edwards, E. (2013). Measurement in the psychology of religiousness and spirituality: Existing measures and new frontiers. In K. I. Pargament, J. J. Exline, \& J. W. Jones (Eds.), APA handbook of 
Available Online at http://journal.unismuh.ac.id/index.php/otoritas

Otoritas : Jurnal Ilmu Pemerintahan, 8 (2), October, 2018, 156

psychology, religion, and spirituality (Vol 1): Context, theory, and research (Vol. 1, pp. 51-77). Washington, D.C.: American Psychological Association.

Hill, P. C., \& Hood, R. W. (1999). Measures of religiosity. Birmingham, Alabama: Religious Education Press.

Hill, P. C., \& Pargament, K. I. (2003). Advances in the conceptualization and measurement of religion and spirituality: Implications for physical and mental health research. American Psychologist, 58(1), 64-74.

Hill, P. C., Pargament, K. I., Hood, R. W., McCullough, Jr., M. E., Swyers, J. P., Larson, D. B., \& Zinnbauer, B. J. (2000). Conceptualizing religion and spirituality: Points of commonality, points of departure. Journal for the Theory of Social Behaviour, 30(1), 5177.

Hoge, D. R. (1972). A validated intrinsic religious motivation scale. Journal for the Scientific Study of Religion, 11(4), 369-376.

Houston, D. J., Freeman, P. K., \& Feldman, D. L. (2008). How naked is the public square?: Religion, public service, and implications for public administration. Public Administration Review, 68(3), 428-444.

Hula, R., Jackson-Elmoore, C., \& Reese, L. (2007). Mixing God's work and the public business: A framework for the analysis of faith-based service delivery. Review of Policy Research, 24(1), 67-90.

Hyman, C., \& Handal, P. J. (2006). Definitions and evaluation of religion and spirituality items by religious professionals: A pilot study. Journal of Religion and Health, 45(2), 264282.
Kaiser, H. F. (1974). An index of factorial simplicity. Psychometrika, 39(1), 3136.

King, J. E., \& Crowther, M. R. (2004). The measurement of religiosity and spirituality: Examples and issues from psychology. Journal of Organizational Change Management, 17(1), 83-101.

King, S. M. (2007). Religion, spirituality, and the workplace: Challenges for public administration. Public Administration Review, 67(1), 103114.

Koenig, H. G., Al Zaben, F., Khalifa, D. A., \& Al Shohaib, S. (2015). Measures of religiosity. In G. J. Boyle, D. H. Saklofske, \& G. Matthews (Eds.), Measures of personality and social psychological constructs (pp. 530561). Amsterdam, The Netherlands: Academic Press.

Krauss, E. S., Hamzah, A., Juhari, R., \& Abd. Hamid, J. (2005). The Muslim Religiosity-Personality Inventory (MRPI): Towards understanding differences in the Islamic religiosity among the Malaysian youth. Pertanika Journal of Social Sciences \& Humanities, 13(2), 173-186.

Lewis, J. S., \& Geroy, G. D. (2000). Employee spirituality in the workplace: A cross-cultural view for the management of spiritual employees. Journal of Management Education, 24(5), 682-694.

Lowery, D. (2005). Self-reflexivity: A place for religion and spirituality in public administration. Public Administration Review, 65(3), 324-334.

MacKenzie, S. B., Podsakoff, P. M., \& Podsakoff, N. P. (2011). Construct measurement and validation 
Available Online at http://journal.unismuh.ac.id/index.php/otoritas

Otoritas : Jurnal Ilmu Pemerintahan, 8 (2), October, 2018, 157

procedures in MIS and behavioral research: Integrating new and existing techniques. MIS Quarterly, 35 (2), 293-334.

Mahudin, N. D. M., Noor, N. M., Dzulkifli, M. A., \& Janon, N. S. (2016). Religiosity among Muslims: A scale development and validation study. Makara Human Behavior Studies in Asia, 20(2), 109-120.

McClelland, D. (1961). The achieving society. Princeton, NJ: Nostrand.

McClelland, D. (1965). N achievement and entrepreneurship: A longitudinal study. Journal of Personality and Social Psychology, 1(4), 398-392.

Miller, A. N., \& Teel, S. (2011). A content analysis of research on religion and spirituality in general communication and health communication journals. Health Communication, 26(7), 615-620.

Muljono, P. (2013). Negotiating gender and bureaucracy: Female managers in Indonesia's Ministry of Finance. Ph.D Thesis in the University of East Anglia.

Murken, S., \& Shah, A. A. (2002). Naturalistic and Islamic approaches to psychology, psychotherapy, and religion: Metaphysical assumptions and methodology-A discussion. International Journal for the Psychology of Religion, 12(4), 239254.

O'Connell, B. J. (1975). Dimensions of religiosity among Catholics. Review of Religious Research, 16(3), 198-207.

Oey-Gardiner, M. (2002). And the winner is ...: Indonesian women in public life. In K. Robinson \& S. Bessell (Eds.), Women in Indonesia: Gender, equity and development (pp. 100-112). Singapore: ISEAS.

Osman-Gani, Aa. M., Hashim, J., \& Ismail, Y. (2012). Establishing linkages between religiosity and spirituality on employee performance. Employee Relations, 35(4), 360-376.

Pargament, K. I. (1999). The psychology of religion and spirituality?: Yes and no. International Journal for the Psychology of Religion, 9(1), 3-16.

Peterson, S. A., \& Greil, A. L. (1990). Death experience and religion. OMEGA Journal of Death and Dying, 21(1), 75 $-82$.

Sood, J., \& Nasu, Y. (1995). Religiosity and nationality: An exploratory study of their effect on consumer behavior in Japan and the United States. Journal of Business Research, 34(1), 1-9.

Tabachnick, B. G., \& Fidell, L. S. (2007). Using multivariate statistics (5th ed.). Boston, MA: Allyn \& Bacon.

Thompson, B. (2004). Exploratory and confirmatory factor analysis: Understanding concepts and applications. Washington, DC: American Psychological Association.

Tracey, P. (2012). Religion and organization: A critical review of current trends and future directions. The Academy of Management Annals, 6(1), 87-134.

Voas, D., McAndrew, S., \& Storm, I. (2013). Modernization and the gender gap in religiosity: Evidence from crossnational European surveys. Kolner Zeitschrift Fur Soziologie Und Sozialpsychologie, 65(Suppl 1), 259283.

Wang, J., \& Yuan, H. (2011). Factors 
Available Online at http://journal.unismuh.ac.id/index.php/otoritas

Otoritas : Jurnal Ilmu Pemerintahan, 8 (2), October, 2018, 158

affecting contractors' risk attitudes in construction projects: Case study from China. International Journal of Project Management, 29(2), 209-219.

Weaver, A. J., Flannelly, L. T., Flannelly, K. J., Koenig, H. G., \& Larson, D. B. (1998). An analysis of research on religious and spiritual variables in three major mental health journals, 1991-1995. Issues in Mental Health Nursing, 19(3), 263-276.

Weaver, A. J., Flannelly, L. T., Garbarino, J., Figley, C. R., \& Flannelly, K. J. (2003). A systematic review of research on religion and spirituality in the Journal of Traumatic Stress: 19901999. Mental Health, Religion \& Culture, 6(3), 215-228.

Weaver, A. J., Samford, J. A., Morgan, V. J., Larson, D. B., Koenig, H. G., \& Flannelly, K. J. (2002). A systematic review of research on religion in six primary marriage and family journals: 1995-1999. The American Journal of Family Therapy, 30(4), 293 -309 .

Weber, M. (1930). The Protestant Ethic and the spirit of capitalism. New York: Allen \& Unwin.

Westerman, J. W., Whitaker, B. G., \& Hardesty, A. (2013). Belief in God: The differential prediction of workplace values. Journal of Management, Spirituality \& Religion, 10(4), 324-341.

Wilkes, R. E., Burnett, J. J., \& Howell, R. D. (1986). On the meaning and measurement of religiosity in consumer research. Journal of the Academy of Marketing Science, 14(1), 47-56. 